\title{
An innovative cooperative model for the Master Degree Project of Architecture. Overcoming the traditional system.
}

\section{Rosa-Jiménez, Carlos ${ }^{a}$; Nebot, Nuria ${ }^{a}$ and García-Moreno, Alberto E. ${ }^{\text {a }}$}

${ }^{a}$ Department of Art and Architecture, Universidad de Málaga, Spain.

\begin{abstract}
Although the Bologna's process has highlighted the need to develop deep and structural changes in the educational institutions, there is a scarce bibliography on innovation projects in Master Degree Projects, specifically in the field of Architecture. This paper is part of a educational innovative reaserch project that is proposing a cooperative process-and-product modelbased for MDP. The model is developed in three stages, from collaborative learning action groups to indivual project. At the end of the process the student has developed three documents: a presentation, a product and a daily-portfolio. Finally, MDP assessment is the sum of three evaluations.
\end{abstract}

Keywords: Master Degree Project; Architecture; Cooperative learning 


\section{Introduction}

The Master Degree Project (MDP) is the normal excercise of a Master of Architecture (MArch) Thesis in Spain. It is presented as a propitious time for students to turn around and demonstrate their professional training, at the end of their initial training process. Although the Bologna's process has highlighted the need to develop deep and structural changes in the educational institutions, there is a scarce bibliography on innovation projects in MDP, specifically in the field of Architecture. This paper is part of a educational innovative reaserch project developed in the School of Architecture of Málaga University ${ }^{1}$ that is proposing a cooperative model-based for MDP. Since 2010, the MArch is replacing the Bachelor of Architecture (BArch), and the MDP is replacing the Bachelor Degree Project (BDP). In both cases, the Spanish educational law states two clear conditions:

a) Presentation and defense of an original exercise carried out individually, before a university defence committee that must include at least one professional of recognized prestige proposed by the professional organizations.

b) Elaboration of an integral architectural project of a professional nature in which all the competences acquired in the career are synthesized, developed to the point of demonstrating sufficiency to determine the complete execution of the building works on which to see, with compliance of the applicable technical and administrative regulations.

The students' relationship with the MDP/BDP can be considered 'special' and exceptional regarding other Bachelor of Science in Engineering. In Architecture, the temporal duration of 30 ECTS (one semester) is one of the highest in technical degrees. Although there is no data to confirm this, an MDP/BDP done in one semester is a very rare practice because students spend more than one semester to complete it (even one or two years). By other hand, students leave a learning model, in which the same professor teaches, puts objetives and evaluates them. In MDP, the advisor (or tutor) replaces the professor's role, and students have to plan their own work schedule and objectives. This new situation has negative pedagogical consequences:

a) There is a contradiction in the 'individual' realization of a MDP. While the professional and research world tends to create multidisciplinary work teams, the individual figure of the architect is insisted on as creator and generator of the project.

b) The sole examination done by a 'defence committee' is an obsolete model (Iborra, 2011). It is imported from the Doctorate's degree where the number of students is normally reduced and has difficulties of application in Bachelor's or Master's degrees with a large

\footnotetext{
${ }^{1}$ PIE-15-146 Collaborative educational innovation actions for the tutoring of Master's Thesis (2015-17).
} 
number of students. In this case, the committee has serious problems to study and assess a big amount of MDPs.

c) In regard to 'elaboration of an integral project of architecture of professional nature'. There are problems to define the terms 'integral project' and 'professional nature'. A professional project of architecture is a work made according to norms of presentation marked by the local Official Architect's Association and limited by the normative compliance of the legislation in a wide spectrum: urban regulations, building law, and technical norms. The project comprises memories, plans, technical specifications, budgets and annexes, regardless of the elaboration of models, given the legal implications that the professional work has.

\subsection{Literature}

Due to the influence of the professional world, MDP has traditionally focused on the finalproduct result, however, in the academic and teaching field, the product is the result of a learning process. According to Rekalde Rodríguez (2011), conception, design, development and evaluation of MDP should be conceived as a learning process where the Master degree's competences are integrated and visualized. Thus, MDP needs to adopt a more proactive role to overcome four constraints:

(a) Overcoming the time: the MDP before the MDP.

Iborra (2011) proposes to carry out the BDP/MDP in parallel with the degree itself, from the moment a student is enrolled in the first course, although it is present or integrated at the end of the process. This model collides with the assumed idea that one first know and then apply what is known, replacing it with the idea that 'we learn from our practical experience'.

(b) Overcoming individual work: a Cooperative-learning Action Group (CAG).

The MDP model should follow an PBL (problem-based learning) methodology defined by Barrows (1986) as a pupil-centered self-directed learning model that occurs in small groups, where advisors (or tutors) act as facilitators of the learning process. For this reason, the creation of groups of five to eight people (Exley and Dennick, 2007) at the beginning of MDP can have a very positive effect. In the advantages of group work, Benito and Cruz (2005) point out that imagination, creativity, and experience is favored. Small size groups encourage collective spirit and motivation. It allows developing different approaches to the problems. While the main drawbacks are personal and/or potential conflicts of interest for sharing information about a project that is known to end individually. 
The incorporation of a 'cooperative learning' in the PBL methodology adds a situation of equality and collaboration in the conditions of the group. According to Deutsch (1949:21): " a cooperative social situation is one in which the goals of the separated individuals are so united that there is a positive correlation between the attainment and their goals, in such a way that an individual achieves his goal if and only if the other participants also achieve theirs".

Within the framework of these cooperative groups, Rekalde Rodríguez (2011) proposes the Learning Group in Action (LGA). A concept based on MC Gill and Beaty (1995)'s studies, where each student "develops study in group, respecting the rules of confidentiality, respect and collective commitment. In this context, the functions that the tutor must develop will be, among others: (a) to favor systematic and argumentative reflection; (b) stimulate the search for research resources; (c) promote the analysis leading to the learning of the situations lived and ensure respect for the group itself". This is feasible, since the student's satisfaction with the advisor is high in the technical careers (Álamo et al., 2011), in addition, the LGA is characterized by an advisor-group interaction for planning the meetings, defining the themes, which are not imposed by the advisor but agreed by both.

(c) Overcoming the format: the digital platforms to integrate process and product.

However, the progressive incorporation of the BIM (Building Information Modeling) is assuming a renovation in the way of presenting a project. The BIM not only involves the virtual modeling of the building and its connection to the database, but also understand that the project is not a closed document to become an open platform where the different agents involved in the construction interact, along the building's life cycle.

In addition, we are immersed in a digital literacy (Prensky, 2001), therefore, it should be encouraged to present the documentation from the Multimedia, that is, by managing all the resources that allow us both to explain the process and explain the product. According to Iborra (2011) the development of video montages, audio, images, blogs, wikis, videoblogs, recordings of activities carried out that could be presented as evidence of the competencies developed, could complement the presentation of a written work defended orally before a committee.

(d) Overcoming the evaluation.

Authors such as Bonilla Priego, Fuentes Moraleda, Vacas Guerrero, \& Vacas Guerrero, (2012) propose a double assessment by the advisor and the committee through a series of indicators depending on the competencies that must be acquired. This means that the committee focuses on the final product (the project) evaluation, while the advisor focuses on the process (the portfolio) evaluation. Even the cooperative phases can include students' self-assessments or co-assessments. 


\section{A New Process-and-product Model for MDP}

From this new perspective, the proposed process-and-product model (see Fig. 1) divides the MDP into two aspects: the learning process (the portfolio) and the final product (the project). The learning process takes place in four phases: the collaborative process, the individual process, the evaluation and the disemaniation of results. In this way, what is finally given is an individual exercise but with a group work support.

(1) At the collaborative process (first semester), the students are organized in several CAGs led by one or several advisors. They analyses the society needs of the selected study area. At the end of this stage, students must individually define the objectives of their project, the study area where each student will develop his individual project, with a definition of the program.

(2) At the individual process (second semester), each student develops his individual project-product guided by the advisor. The student must also prepare a work portfolio collecting all the evidences of his work process.

(3) At the evaluation stage, the student must prepare a presentation to support the defense of his project. In this way, at the end of the process the student has developed three documents: a presentation, a product and a daily-portfolio. MDP assessment is the sum of three evaluations, whose weight $[\mathrm{A}, \mathrm{B}, \mathrm{C}]$ will be determined according to the characteristics of the project:

a) The committee's assessment of the student's public presentation and defence [weight A].

b) The committee's assessment of the MDP as a product [weight B].

c) The advisor's assessment of the MDP as a learning process [weight $\mathrm{C}$ ]. Instruments and evidences of learning may be based on:

- Design and development of MPD

- Portfolio through the learning diary or logbook

- Self-assessment and co-evaluation

(4) Finally, the results of the MPD will be include on the univesity repository. 


\section{Discussion and conclusion}

As Iborra (2011) proposes, the MDP model is developed at the beginning of Master's degree, in a pedagogical environment that starts from the collaborative work and concludes with an individual project, according to what is required by the Spanish state regulations. It is a model in which the student is closer to a group work environment at the beginning and proposes an environment of individual creativity at the end. However, the individual result is part of the overall and collaborative response to the study area, so the model does not support different areas or another thematics proposed individually by a student.

The incorporation of the portfolio is related to the MDP research process and, according to the experience of Barragán Sánchez (2005), facilitates the evaluation of the process and the product, motivating the student in the reflection on the learning process and developing collaborative skills However, the proposed model has some drawbacks: first, the adviser's work increases considerably, and secondly, the evaluation becomes a complex process. Therefore, the proposal needs a practical application to assess the improvements proposed. 


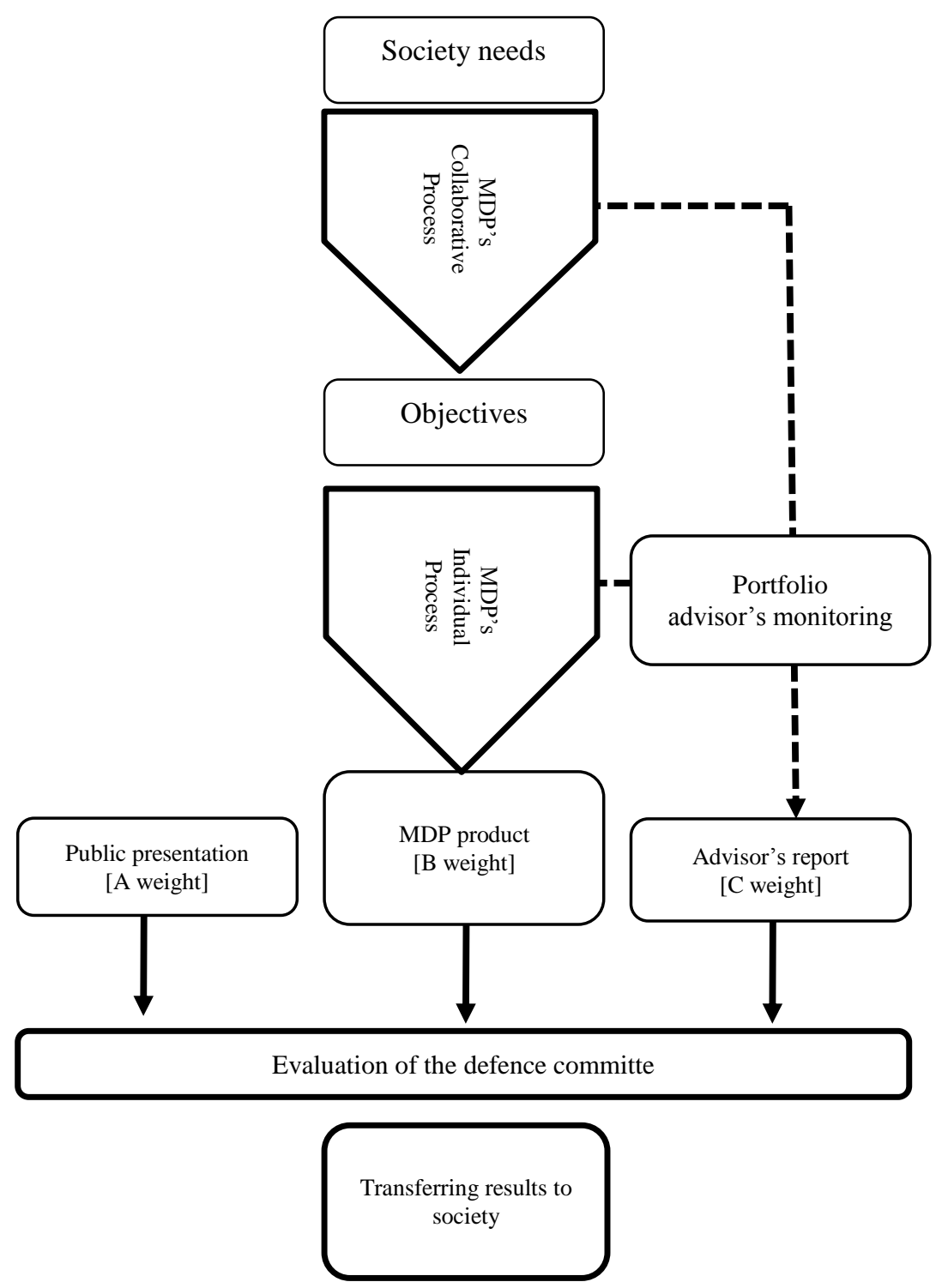

Figure 1. A cooperative model for a MDP of Architecture. Source:Authors (2017). 


\section{References}

Álamo, J. M. del, Cuadrado, F., Fernández, J. I., Malagón, P., Trapero, R., \& González Tirados, R. M. (2011). A characterization of Master Thesis advisor skills in Engineering Education. Aula Abierta, 39(2), 123-136. Retrieved from http://dialnet.unirioja.es/servlet/articulo?codigo=3621399

Barragán Sánchez, R. (2005). El Portafolio , metodología de evaluación y aprendizaje de cara al nuevo Espacio Europeo de Educación Superior . Una experiencia práctica en la Universidad de Sevilla. Revista Latinoamericana de Tecnología Educativa, 4(1), 121140.

Benito, A. y Cruz, A. (2005). Nuevas claves para la docencia universitaria en el Espacio Europeo de Educación Superior. Madrid: Narcea.

Barrows, H. S. (1986). A taxonomy of problem-based learning methods. Medical Education, 20(6), 481-486. http://doi.org/10.1111/j.1365-2923.1986.tb01386.x

Bonilla Priego, M. J., Fuentes Moraleda, L., Vacas Guerrero, C., \& Vacas Guerrero, T. (2012). An analysis of the Final Dissertation Assessment Process in new degrees. Educade: Revista de Educación En Contabilidad, Finanzas Y Administración de Empresas, (3), 5-21. Retrieved from http://dialnet.unirioja.es/servlet/articulo?codigo $=4156105 \&$ info $=$ resumen\&idioma $=E N$ G

Deutsch, M. (1949). A theory of cooperation and competition. Human Relations, Human Rela(2), 129-152. http://doi.org/0803973233

Exley, K. y Dennis, R. (2007). Enseñanza en pequeños grupos en Educación Superior. Madrid: Narcea

Iborra, A. (2011). Concepciones y asunciones subyacentes al taller sobre "El Trabajo Fin de Grado”. Evaluación Global de Los Resultados Del Aprendizaje En Las Titulaciones Dentro Del Espacio Europeo de Educación Superior, 369-382.

Mc Gill, I. \& Beaty, L. (1995). Action Learning: A guide for professional, man- agement and educational development. London: Kogan Page

Prensky, M. (2001). Digital Natives, Digital Immigrants Part 1_ On the Horizon_ Vol 9, No 5. On The Horizon, 9(5), 1-6. http://doi.org/10.1001/archderm.143.4.515

Rekalde Rodríguez, I. (2011). ¿Cómo afrontar el trabajo fin de grado? Un problema o una oportunidad para culminar con el desarrollo de las competencias. Revista Complutense de Educación, 22(2), 179-193. http://doi.org/10.5209/rev_RCED.2011.v22.n2.38488 